\title{
Appraisal Arbitrage: Closing The Floodgates on Hedge Funds and Activist Shareholders
}

Author: Craig Boyd*

\section{INTRODUCTION}

Arbitrage. The words that come to mind when attempting to define "arbitrage" inevitably include terms such as lies, trickery, unfair play, and deception. Intuition calls us to correct the system and level the playing field to eliminate whatever mechanism allows such arbitrageurs their ability to exploit a loophole in the system. Unfortunately, when a party reaps the benefits of system inefficiencies, surrounding organizations bear the burden of an unfair economic advantage. The mechanism enabling such arbitrage requires correction not only to restore marketplace balance but also to remedy the negative impact inflicted on related corporations.

A particular form of arbitrage is growing in Delaware appraisal litigation as hedge funds and activist shareholders exploit the leniency of Delaware General Corporation Law ("DGCL") section 262. When a corporation decides to acquire or merge with another corporation, section 262 provides shareholders that dissent or abstain from a merger "appraisal rights" granting shareholders the ability to challenge the impending merger price through an appraisal action. ${ }^{1}$ In the past decade, the Delaware court system has seen a tremendous growth from shareholders fixated on bringing appraisal claims. However, these claims are not being brought by the dissenting minority shareholders that section 262 was designed to protect. The surge of new plaintiffs has primarily been hedge funds and activist shareholders attempting to take advantage of an unjust investment strategy that is now commonly referred to as "appraisal arbitrage."

Appraisal arbitrage occurs when hedge funds and activist

* J.D. Candidate 2017, University of Kansas School of Law; B.A. 2012, MidAmerica Nazarene University. I would like to thank Professor Webb Hecker for his guidance and invaluable feedback throughout the writing process. I would also like to thank the University of Kansas Law Review for their hard work and assistance in publishing this Comment. Most importantly, I would like to thank my wife, Sara, for providing endless love, support, and laughter.

1. Del. Code ANN. tit. 8, § 262(a) (West 2006 \& Supp. 2016). 
shareholders take advantage of statutory appraisal rights by acquiring a sizeable amount of shares shortly after a merger is announced with the intention of asserting appraisal rights in the future. ${ }^{2}$ These arbitrageurs seek to "buy" appraisal claims and prey on merger transactions as they deem fit. Such appraisal actions are being brought by very sophisticated entities that have specialized in an investment strategy aimed at taking advantage of minority shareholder appraisal rights. ${ }^{3}$ Overall, such actions exploit a statutory right intended to protect and provide a remedy for minority shareholders that have been taken advantage of by abusive mergers.

By providing concentrated legislative reforms to section 262, the amount of appraisal arbitrage being performed by hedge funds and activist shareholders can be controlled and limited substantially. The first step to solving this pressing issue requires the Delaware legislature to amend section 262 to prohibit the purchase of a merging corporation's shares after the record date (or the date that determines shareholder eligibility to vote in a pending merger), effectively preempting the ruling of In re Appraisal of Transkaryotic Therapies Inc. ${ }^{4}$ This Comment will show that the Delaware Court of Chancery's decision in Transkaryotic increases the lucrative nature of an appraisal action by allowing hedge funds and activist shareholders the opportunity to survey market conditions before buying a company's stock. Targeted reforms that eliminate a hedge fund's knowledge of market conditions up to the effective date of the merger will substantially increase the risks of appraisal arbitrage. ${ }^{5}$ The suggested reforms in Part III of this Comment stand to decrease the amount of appraisal actions brought by hedge funds and activist shareholders, while continuing to protect the long-term minority shareholders the statute was designed to encompass.

The second reform requires the Delaware legislature to eliminate, or at least substantially reduce, the statutory interest rate provided in section

2. Abigail Pickering Bomba et al., New Activist Weapon - The Rise of Delaware Appraisal Arbitrage: A Survey of Cases and Some Practical Implications, FRIED, FRANK, HARRIS, SHRIVER \& JACOBSON LLP (June 18, 2014), http://www.friedfrank.com/siteFiles/Publications/FINAL\%20\%206182014\%20TOC\%20Memo\%20-\%20New\%20Activist \%20Weapon-

\%20The\%20Rise\%20of\%20Delaware\%20Appraisal\%20Arbitrage.pdf.

3. Charles R. Korsmo \& Minor Myers, Appraisal Arbitrage and the Future of Public Company M\&A, 92 WASH. U. L. REV. 1551, 1553 (2015).

4. In re Appraisal of Transkaryotic Therapies, Inc., No. 1554-CC, 2007 WL 1378345, at *5 (Del. Ch. May 2, 2007).

5. Gaurav Jetley \& Xinyu Ji, Appraisal Arbitrage -Is There a Delaware Advantage?, 71 Bus. LAW. 427, 433-36 (2016). 
262(h) as a further step to the pending reforms. ${ }^{6}$ Section 262(h) provides that dissenting shareholders will be awarded statutory interest that accrues at 5\% over the Federal Reserve discount rate for the duration of their appraisal claim regardless of the outcome. ${ }^{7}$ This has been seen as an extremely advantageous aspect for appraisal petitioners because it provides a relatively high interest rate when compared to a regular investment's interest rate. ${ }^{8}$ The statutory interest rate available to appraisal petitioners limits the risk inherent in bringing an appraisal claim and likely provides appraisal arbitrageurs a substantial investment profit regardless of their claim's success. Abolishing or significantly lowering the statutory interest rate eliminates the safety net provided to potential appraisal arbitrageurs. Overall, reforms to section 262 eliminating the purchase of shares after the record date and limiting statutory interest stand to limit the amount of appraisal arbitrage engaged in by predatory hedge funds and reduce the unintended litigation imposed on the Delaware court system.

This Comment traces the evolution of shareholder appraisal rights under section 262 and explores the solution to the rapidly growing problem of appraisal arbitrage. Part II of this Comment documents the factors leading to the rise of appraisal arbitrage and the aspects that have made it a lucrative investment strategy for hedge funds and activist shareholders. Part III then proposes a two-pronged reform to section 262 and examines the economic and policy incentives to support such reforms as the best solution to ending appraisal arbitrage. Finally, this Comment proposes that targeted reforms to section 262 will further the legislative purpose behind section 262, and substantially limit appraisal arbitrage's harmful effects on merger transactions across the country.

\section{BACKGROUND}

Before discussing potential reforms to limit appraisal arbitrage, it is important to understand the purpose behind section 262's formation, and the evolution of case law that has given life to appraisal arbitrage. Appraisal arbitrage has a humble beginning with the codification of section 262 and the creation of appraisal rights. Section 262 allows minority shareholders that dissent from an impending merger the ability to petition the court and potentially receive what they perceive as the fair

\footnotetext{
6. S.B. 75,148 th Gen. Assemb. (Del. 2015).

7. Del. Code AnN. tit. 8, § 262(h) (West 2006 \& Supp. 2016).

8. Jason Mei, IX. Appraisal Arbitrage: Investment Strategy of Hedge Funds and Shareholder Activists, 34 ReV. BANKING \& Fin. L. 83, 86 (2014).
} 
value of their shares. ${ }^{9}$ In recent years, case law interpretations such as In re Appraisal of Transkaryotic Therapies, Inc. ${ }^{10}$ and In re Appraisal of Ancestry.com, Inc. ${ }^{11}$ have given life to the practice of appraisal arbitrage by minimizing its risk and increasing its potential profitability. ${ }^{12}$ Hedge funds and activist shareholders across the country have flocked to the practice of appraisal arbitrage by purchasing large amounts of a target company's shares after a merger has been announced with the sole intention of bringing an appraisal claim in the Delaware court. ${ }^{13}$ The Delaware State Bar Association has proposed amendments to section 262 , but the Delaware legislature has yet to propose any legislation adopting these amendments likely because they fail to provide a viable solution to end appraisal arbitrage. ${ }^{14}$ Lastly, a positive trend has emerged in Delaware appraisal actions with the courts tending to favor the merger price as a fair assessment of the appraisal value in reasonable situations rather than other costly and confusing valuation methods. ${ }^{15}$

\section{A. Usage and History of Section 262}

Historically, a corporation's board of directors was required to obtain unanimous shareholder approval prior to all significant corporate decisions including the decision to execute a merger. ${ }^{16}$ The unanimous shareholder requirement provided a single shareholder with an extremely significant veto power, enabling the shareholder to block all corporate

9. Del. Code ANN. tit. 8, § 262(a) (West $2006 \&$ Supp. 2016) (providing the purpose of the statute is to protect dissenting shareholders from being offered unfair valuations on their shares).

10. No. 1554-CC, 2007 WL 1378345 (Del. Ch. May 2, 2007).

11. No. 8173-VCG, 2015 WL 66825 (Del. Ch. Jan. 5, 2015).

12. Daniel E. Wolf et al., Appraisal Rights-The Next Frontier in Deal Litigation?, KIRKLAND

LLP (May

1 2013) http://www.kirkland.com/siteFiles/Publications/MAUpdate 050113.pdf.

13. Bomba et al., supra note 2, at 1 .

14. Brian T. Frawley et al., Sullivan \& Cromwell discusses Delaware Legislation Saying No to "Loser-Pays" Fee-Shifting Bylaws But Yes to Forum-Selection Bylaws for Stock Corporations, COLUM. L. SCH. BLUE SKY BLOG (June 16, 2015), http://clsbluesky.law.columbia.edu/2015/06/16/sullivan-cromwell-discusses-delaware-legislationsaying-no-to-loser-pays-fee-shifting-bylaws-but-yes-to-forum-selection-bylaws-for-stockcorporations- $2 /$.

15. See, e.g., Huff Fund Inv. P'ship v. CKx, Inc., No. 6844-VCG, 2013 WL 5878807, at*1 (Del. Ch. Nov. 1, 2013), aff'd, 2015 WL 631586 (Del. Feb. 12, 2015) (finding that "use of the merger price to determine fair value is appropriate in this matter"); In re Appraisal of Ancestry.com, Inc., No. 8173-VCG, 2015 WL 399726, at*24 (Del. Ch. Jan. 30, 2015); Merion Capital LP v. BMC Software, Inc., No. 8900-VCG, 2015 WL 6164771, at*18 (Del. Ch. Oct. 21, 2015).

16. In re Appraisal of Transkaryotic Therapies, Inc., No. 1554-CC, 2007 WL 1378345, at *3 (Del. Ch. May 2, 2007). 
actions with just a single vote. ${ }^{17}$ This voting requirement created a "hold up" problem where any shareholder could prevent a beneficial change from being performed in a corporation. ${ }^{18}$

1. The Delaware Legislature's Response: Section 262

The Delaware legislature responded by enacting statutes that allow corporations to execute fundamental corporate changes with majority shareholder consent rather than unanimity. ${ }^{19}$ In anticipation of a merger situation "the Legislature created appraisal rights in an effort to compensate minority holders for the loss of the veto power and to give dissenters the right to demand fair value of shares." 20 The legislature created appraisal rights to strike a balance of power between majority and minority shareholders by providing majority shareholders a broader authority to make beneficial decisions on the company's behalf and foster growth. $^{21}$ In contrast, appraisal rights protect minority shareholders by providing dissenting shareholders a way out of an unwanted transaction while also compensating them with a fair value for their shares. ${ }^{22}$

Recently, the primary purpose of appraisal rights has shifted its focus to primarily protecting minority shareholders from majority shareholders engaged in conflict transactions. ${ }^{23}$ This shift became a larger focus when courts and legislatures expanded the scope of a majority shareholder's power, thus allowing the leaders of a corporation to conduct a merger forcing minority shareholders out of the corporation and compensating them with cash. ${ }^{24}$ Since this change, appraisal right's primary focus shifted to protecting minority shareholders from the overreaching actions of majority shareholders. ${ }^{25}$

17. R. Franklin Balotti \& Jesse A. Finkelstein, Delaware Law of Corporations and BuSINESS ORGANIZATIONS $\S 9.42$ (3d ed. 2005 \& Supp. 2016).

18. Robert B. Thompson, Exit, Liquidity, and Majority Rule: Appraisal's Role in Corporate Law, 84 GEO. L.J. 1, 13 (1995).

19. Transkaryotic, 2007 WL 1378345 at $* 3$.

20. Id.

21. Thompson, supra note 18 , at 11-13.

22. Id. at 13 .

23. Id. at 11 .

24. Id. at $20-21$

25. Id. at 22 . 
2. Procedural Requirements to Bring an Appraisal Action

Under Delaware law, appraisal rights can be triggered by some but not all merger transactions. ${ }^{26}$ Section 262(b) provides for a "market-out exception" that eliminates appraisal rights for shareholders of companies that are widely traded, ${ }^{27}$ unless such shareholders are paid consideration in cash as a result of their force out. ${ }^{28}$ However, any company may provide appraisal rights to shareholders in its certificate of incorporation. $^{29}$

Under section 262(a), appraisal rights are limited to shareholders who dissent from a forced merger transaction. ${ }^{30}$ Dissenting shareholders are required to comply with multiple procedural requirements to be considered eligible for an appraisal remedy. ${ }^{31}$ Such procedural requirements include: voting in opposition to the merger or abstaining from voting altogether, producing a written demand to the company for appraisal rights, commencement of an appraisal proceeding within 120 days after the effective date of the merger, and each shareholder maintaining ownership of their shares through the effective date of the merger. $^{32}$ In addition, dissenting shareholders have the ultimate burden of establishing their right to an appraisal of their stock's value by the court. $^{33}$ Although appraisal rights are filled with procedural requirements, an evolution of case law has provided substantial motivation for hedge funds and activist shareholders to take advantage of appraisal rights.

\section{B. The Rise of Appraisal Arbitrage}

Over the past decade, appraisal claims have had a limited presence in Delaware courts and have been insignificant in terms of Delaware legislative reform. In the past, appraisal claims have not provided a significant reason for concern because appraisal claims have maintained a consistent correlation to the amount of mergers taking place in the

\footnotetext{
26. Del. Code ANN. tit. 8, § 262(b)(1) (West 2006 \& Supp. 2016).

27. Id. "Widely traded" under section 262(b)(1) means a corporation's shares are either: "(i) listed on a national securities exchange or (ii) held of record by more than 2000 holders." Id.

28. $\S 262(b)$.

29. $\S 262(\mathrm{c})$.

30. $§ 262(a)$.

31. $\S 262(\mathrm{~d})$.

32. § 262(d)-(e).

33. Schneyer v. Shenandoah Oil Corp., 316 A.2d 570, 573 (Del. Ch. 1974).
} 
marketplace. $^{34}$ From 2004 to 2007, the number of appraisal petitions stayed fairly consistent with the amount of merger transactions and both fell after the financial crisis. ${ }^{35}$

However, in the past decade, there has been a dramatic increase in the amount of appraisal claims brought by minority shareholders. In 2011, the amount of appraisal claims nearly doubled, and by 2013, the percentage of transactions that attracted an appraisal petition tripled from $5 \%$ to $15 \%$ of all merger transactions. ${ }^{36}$ In addition, the value at stake in each individual appraisal claim has significantly increased. In 2013, dissenting shareholders brought an aggregate amount of $\$ 1.5$ billion in appraisal claims. ${ }^{37}$ This amount is ten times the value brought by dissenting shareholders in 2004, and more than five times the highest value of dissenting shares in the five years prior. ${ }^{38}$

Interestingly, the amount of appraisal claims and the overall value at issue have all increased independently and by greater degrees than the amount of mergers taking place. ${ }^{39}$ This phenomenon is due to the overwhelming growth of specialized litigation used by repeat hedge funds and activist shareholders designed to take advantage of minority shareholder appraisal statutes. ${ }^{40}$

There are multiple factors that have contributed to appraisal arbitrage's recent development as a lucrative investment strategy. The main factor contributing to this phenomenon arose in the 2007 case of In re Appraisal of Transkaryotic Therapies, Inc., ${ }^{41}$ where the Delaware Court of Chancery's decision resulted in a significant incentive for hedge funds and activist shareholders to practice appraisal arbitrage. ${ }^{42}$ The holding in Transkaryotic was recently reaffirmed by the Delaware Court of Chancery in In re Appraisal of Ancestry.com, Inc. ${ }^{43}$ In addition to the case law developments in this area, the method of calculating interest on pending claims in section 262(h) provides additional incentive for

\footnotetext{
34. Korsmo \& Myers, supra note 3, at 1569.

35. Id. ("From 2004 through 2010, the number of appraisal petitions moved roughly in tandem with the general level of merger activity, rising through 2007 and thereafter falling along with the number of mergers after the financial crisis.").

36. Id. at $1569-70$.

37. Id. at 1553 .

38. Bomba et al., supra note 2, at 1.

39. Korsmo \& Myers, supra note 3, at 1569.

40. Mei, supra note 8 , at 83.

41. No. 1554-CC, 2007 WL 1378345, at*5 (Del. Ch. May 2, 2007).

42. Wolf et al., supra note 12, at 1 .

43. No. 8173-VCG, 2015 WL 66825, at *6 (Del. Ch. Jan. 5, 2015).
} 
arbitrageurs to bring claims against merging corporations. ${ }^{44}$ Overall, Delaware's case law interpretation of the statutory language in section 262 has opened the floodgate for hedge funds to take advantage of Delaware's appraisal statutes.

C. Case Summary of In re Appraisal of Transkaryotic Therapies, Inc.

Statutory appraisal was an underutilized remedy prior to the Delaware Court of Chancery's decision in In re Appraisal of Transkaryotic Therapies, Inc. ${ }^{45}$ Statutory appraisal was often not taken advantage of because transactions could be structured to avoid appraisal rights for minority shareholders altogether, and if appraisal was an option, there was a tremendous amount of risk and expense involved in bringing a claim. ${ }^{46}$ The Transkaryotic decision provides one of the first and substantial factors as to why appraisal arbitrage is such a lucrative and successful investment strategy for hedge funds and activist shareholders. The court's decision provides appraisal petitioners with a significant timing advantage to determine the profitability of bringing an appraisal claim.

\section{Transkaryotic Opens the Door for Appraisal Arbitrage}

Appraisal rights under section 262 may only be asserted by shareholders who chose to vote against the merger or abstained from voting altogether. ${ }^{47}$ The plaintiff shareholders asserting an appraisal claim in Transkaryotic purchased the majority of their shares after both the announcement of the merger and the record date for the shareholder meeting, but before the effective date of the merger. ${ }^{48}$ In a typical merger transaction, the merger will be announced to the public and then the record date for the shareholder meeting will be set. The record date is the point in time at which the eligibility of voting shareholders to the transaction is determined. ${ }^{49}$ The issue presented in the case was whether "a beneficial owner, who acquires shares after the record date, must prove that each of its specific shares for which it seeks appraisal was not

\footnotetext{
44. Del. Code ANN. tit. 8, § 262(h) (West 2006 \& Supp. 2016).

45. Transkaryotic, 2007 WL 1378345.

46. Dominick T. Gattuso \& Samuel T. Hirzel, Delaware Insider: Statutory Appraisal: An Old Workhorse with a New Lease on Life, 2015 Bus. L. TODAY 1, 1 (2015).

47. $\S 262(\mathrm{~d})$.

48. Transkaryotic, $2007 \mathrm{WL} 1378345$, at *1.

49. Del. Code ANN. tit. 8, § 213 (West 2006 \& Supp. 2016).
} 
voted in favor of the merger" to remain eligible for appraisal rights. ${ }^{50}$ The defendant argued that a plaintiff bringing an appraisal claim bears the burden of proving that the shares it held were not voted in favor of the merger. ${ }^{51}$ In response, the plaintiffs argued that, in light of modern securities practices, it is impracticable and even impossible due to the intangible nature of the stock market to trace how shares may have been voted when shares are purchased after the record date. ${ }^{52}$

To grasp the logic behind the holding in Transkaryotic, an underlying issue regarding modern securities practices requires further explanation. The majority of shares issued by modern-day public companies no longer exist in a certificated form, but exist "on deposit" with central securities depositories. ${ }^{53}$ "Beneficial owners," such as the plaintiffs in Transkaryotic, enjoy the benefit of ownership-including voting - but their shares may be held by another entity such as a central depository, brokerage firm, bank, and so forth. ${ }^{54}$ These beneficial owners have no traceable ownership claim to specific shares held by central securities depositories. ${ }^{55}$ Therefore, if a beneficial owner's shares have been purchased after the record date, there is no way of proving that their shares were not voted in favor of the merger.

The Chancery court ultimately held that shares acquired after the record date are eligible for appraisal rights under section 262. The court reasoned that under the literal terms of the statutory text, section 262(a) defines a stockholder eligible for appraisal rights as a "holder of record." 56 Therefore, only the record holder's actions may determine perfection of appraisal rights. The ruling in Transkaryotic makes clear that "an investor can wait until just before the stockholder vote on a merger to purchase a target company's shares (after having had the opportunity to review public disclosure and gauge market conditions), and then subsequently file an appraisal claim with respect to those shares." 57 The Transkaryotic decision provides a significant timing advantage for appraisal arbitrageurs and has been a clear factor in the increase of appraisal arbitrage.

\footnotetext{
50. Transkaryotic, $2007 \mathrm{WL} 1378345$, at *1.

51. Id.

52. $I d$. at $* 2$.

53. Eliza W. Swann \& Gregory F. Gewirtz, Dusting Off Appraisal Rights: The Development of a New Investment Strategy, 18 No. 4 M \& A Law. 1, 3 (2014).

54. Id.

55. $I d$.

56. Del. Code ANN. tit. 8, § 262(a) (West 2006 \& Supp. 2016).

57. Swann \& Gewirtz, supra note 53 , at 3-4.
} 
2. The Transkaryotic Court Acknowledges the Potential for Appraisal Arbitrage

Prior to the ruling in Transkaryotic, appraisal rights were not typically considered a lucrative investment or arbitrage strategy because investors assumed they could not buy shares after the record date and then subsequently assert appraisal rights. ${ }^{58}$ The defendants asserted that the court's ruling would undermine the goals of the appraisal statute by "allowing it to be used as an investment tool for arbitrageurs as opposed to a statutory safety net for objecting stockholders." $" 59$ The holding allows appraisal arbitrageurs additional time to make the decision of whether to buy a target company's stock for the purpose of pursuing appraisal rights. ${ }^{60}$ This decision creates a timing advantage for investors that provides them with the ability to analyze a company's proxy statements relating to the sale process, determine if the price is low, assess any pre-closing shareholder litigation, and evaluate the market conditions for an extended period of time. ${ }^{61}$ This provides investors with a distinct advantage by decreasing the possibility of a risky purchase and maximizing the success of an appraisal claim. ${ }^{62}$

The court responded to this argument by noting that the ruling was a direct result of section 262's statutory language. ${ }^{63}$ The language within section 262 clearly provides that appraisal rights are exclusively for the "holder of record." 64 This clear and controlling language directs the court to solely evaluate the holder of record to determine appraisal rights rather than beneficial holders that may have purchased their shares after the record date. Therefore, the solution to the issue of appraisal arbitrage "more properly lies with the Legislature" rather than in the courts. ${ }^{65}$ Overall, the court followed the strict and plain language of section 262, and placed the legislature in a position to "avoid the evil" of appraisal arbitrage. ${ }^{66}$

\footnotetext{
58. Id.

59. In re Appraisal of Transkaryotic Therapies, Inc., No. 1554-CC, 2007 WL 1378345, at *5 (Del. Ch. May 2, 2007).

60. Bomba et al., supra note 2, at 2 .

61. Id.

62. $I d$.

63. Transkaryotic, $2007 \mathrm{WL} 1378345$, at $* 5$.

64. Del. Code ANN. tit. 8, § 262(a) (West 2006 \& Supp. 2016).

65. Transkaryotic, 2007 WL 1378345 , at $* 5$.

66. Id.
} 
3. In re Appraisal of Ancestry.com, Inc. Reaffirms the Holding in Transkaryotic

Since Transkaryotic, Delaware courts have been firm in relying on section 262's statutory language to assert that section 262 does not prohibit the purchase of a company's shares after the record date. In early January of 2015, the Delaware Court of Chancery reaffirmed the Transkaryotic decision in the case of In re Appraisal of Ancestry.com, Inc. ${ }^{67}$ The dissenting shareholder in this appraisal action was Merion Capital, a hedge fund that is one of the largest repeat petitioners in the game of appraisal arbitrage with over $\$ 700$ million invested in Delaware appraisal claims. ${ }^{68}$ Merion bought stock in Ancestry.com after the record date and quickly announced its intention for appraisal of its shares. ${ }^{69}$ As in Transkaryotic, Ancestry.com filed a motion for summary judgment arguing that Merion was not able to show that the shares it purchased after the record date were not voted in favor of the merger. ${ }^{70}$ The court denied Ancestry.com's motion and reaffirmed the ruling in Transkaryotic holding that "the actions of beneficial holders are irrelevant in appraisal matters." share-tracing requirement for all parties that assert appraisal rights would be inappropriate because such a requirement is not found in the statutory language of section $262 .^{72}$ If such a change were implemented, it would be a "legislative, not a judicial, function."

Overall, when looking at both Transkaryotic and Ancestry.com the courts have remained consistent in relying on the plain statutory language in section 262 to decide that a share-tracing requirement is not required for beneficial holders of stock that dissent from a merger transaction. ${ }^{74}$ Ultimately, these holdings allow hedge funds and activist shareholders the opportunity to seek appraisal for shares purchased after a merger's public announcement that possibly have already been voted in favor of the merger. This valuable advantage has been the main factor leading to the increased popularity of appraisal arbitrage and has created

67. In re Appraisal of Ancestry.com, Inc., No. 8173-VCG, 2015 WL 66825, at *7 (Del. Ch. Jan. 5, 2015).

68. Korsmo \& Myers, supra note 3, at 1574-75.

69. Ancestry.com, Inc., 2015 WL 66825, at*2.

70. Id.

71. Id. at $* 6$.

72. Id. at $* 9$.

73. Id.

74. In re Appraisal of Transkaryotic Therapies, Inc., No. 1554-CC, 2007 WL 1378345, at *5 (Del. Ch. May 2, 2007); Ancestry.com, Inc., 2015 WL 66825, at*6. 
a more lucrative and risk-free investment strategy for hedge funds and shareholder activists to take advantage of. ${ }^{75}$ These courts have recently reaffirmed the idea that the Delaware legislature will need to take action to solve appraisal arbitrage because courts will continue to abide by the plain language of the statute. ${ }^{76}$

\section{Section 262(h) and the Statutory Interest Rate Advantage}

Another explanation for the recent dramatic increase in appraisal arbitrage can be linked to the interest rate available to petitioners while in the process of an appraisal claim. ${ }^{77}$ Appraisal petitioners are entitled to statutory interest on their claims by section 262 while their claim is being decided by the Delaware courts. ${ }^{78}$ Delaware amended the statutory language of section $262(\mathrm{~h})$ in $2007^{79}$ to provide that " $[\mathrm{u}]$ nless the Court in its discretion determines otherwise for good cause shown ... interest from the effective date of the merger through the date of payment of the judgment shall be compounded quarterly and shall accrue at $5 \%$ over the Federal Reserve discount rate." 80

\section{The Purpose Behind Statutory Interest}

When a shareholder brings an appraisal claim rather than vote in favor of the merger, the shareholder "loses the traditional benefits of stock ownership: the right to vote stock and to receive payment of dividends or other distribution upon the shares." ${ }^{\text {"1 }}$ Essentially, the shareholder places the investment "in limbo" until the court rules on the petitioner's right to appraisal and determines the fair market value of the shares. ${ }^{82}$ As a result, shareholders have no right to receive income from their ownership in the merging corporation while waiting on an uncertain decision by the court system. In addition, such shareholders must account for the expenses that come with the appraisal process. ${ }^{83}$ This leaves shareholders in an uncomfortable position. The statutory interest

\footnotetext{
75. Gattuso \& Hirzel, supra note 46, at 1 .

76. Ancestry.com, Inc., 2015 WL 66825, at *6.

77. Korsmo \& Myers, supra note 3, at 1579.

78. Del. CodE ANN. tit. 8, § 262(h) (West 2006 \& Supp. 2016).

79. Korsmo \& Myers, supra note 3, at 1580.

80. $\S 262(\mathrm{~h})$.

81. Ala. By-Prods. Corp. v. Cede \& Co. on Behalf of Shearson Lehman Bros., Inc., 657 A.2d 254, 259 (Del. 1995).

82. Gilliland v. Motorola, Inc., 873 A.2d 305, 312 (Del. Ch. 2005).

83. § 262(j).
} 
provided in section 262 is meant to compensate dissenting shareholders while waiting for an appraisal claim to come to fruition. ${ }^{84}$ Absent good cause to find otherwise, minority shareholders will receive $5 \%$ in excess of the Federal Reserve discount rate on the value of their shares, regardless of the claim's outcome. ${ }^{85}$

Section 262 provides that appraisal petitioners will receive statutory interest unless good cause is shown to provide otherwise. ${ }^{86}$ In Merion Capital, LP v. $3 M$ Cogent, Inc., ${ }^{87}$ the court provided that Delaware law does not disfavor an appraisal petitioner because they purchased their shares after the record date for statutory interest purposes. ${ }^{88}$ In addition, statutory interest protects appraisal petitioners from the unfair windfall of a company's free use of their merger proceeds at no cost for the duration of the appraisal action. ${ }^{89}$ The Merion decision made it apparent that a corporation's effort to eliminate a petitioner's interest right under section 262(h) will be extremely difficult. ${ }^{90}$

\section{Statutory Interest as a Means to Appraisal Arbitrage}

The statutory interest rate is a substantial mitigating factor when a shareholder is faced with the substantial risks of bringing an appraisal claim. $^{91}$ Hedge funds and activist shareholders that purchase shares in anticipation of bringing an appraisal claim have the ability to reap the benefits of this statutory interest rate in addition to the long-time shareholders for whom section 262 provides protection. Even if a shareholder dissents from the merger and receives close to nothing or only a small amount over the merger price from the court, "statutory interest may still provide a reasonably competitive rate of return in the current market." 92 Some lawyers have argued that in a period of "ultralow" interest rates, engaging in appraisal litigation can be a lucrative investment opportunity regardless of the overall outcome of the appraisal petition due to the high likelihood of receiving a generous rate of interest. $^{93}$ Additionally, the interest rate is, at a minimum, an offset to

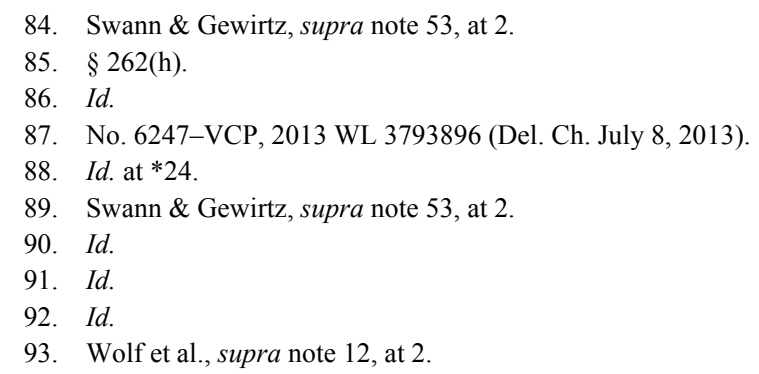


the extended period of illiquidity and litigation costs appraisal arbitrageur's endure during the litigation period. ${ }^{94}$

The potential of a significant return on investment with theoretically little risk can be an incentive for hedge funds and activist shareholders to bring appraisal actions. The Delaware courts have provided that there is a growing "concern about whether the interest rate that the Legislature has set encourages these types of appraisal cases" and provides an incentive for a petitioner to move slowly throughout the appraisal process. $^{95}$ In addition, a sizeable claim can result in a large interest payment that lands on the surviving company's shoulders. ${ }^{96}$ The statutory interest rate raises the threat of a huge interest cost that could possibly force companies into considering unfavorable settlements with aggressive stockholders pursing an appraisal action. ${ }^{97}$ Such a fear presents a substantial threat to corporate mergers, and provides hedge funds and activist shareholders a fair amount of leverage by threatening to impose an extremely large interest payment.

\section{E. The Delaware State Bar Provides Unsatisfactory Reforms to Section 262}

There have been recent reforms relevant to Delaware corporation law presented in Delaware Senate Bill 75. ${ }^{98}$ The Corporate Law Section of the Delaware State Bar Association originally included two reforms attempting to limit the investment practice of appraisal arbitrage (the "Bar's Appraisal Amendments"). However, the Delaware legislature failed to propose legislation to adopt the Bar Appraisal Amendments to section 262 likely because they were unsuccessful in substantially limiting appraisal arbitrage. ${ }^{99}$ The Bar Appraisal Amendments proposed: "(a) would limit otherwise qualified appraisal claims if the claim is below a certain threshold [limit], and (b) toll the accrual of statutory interest on any portion of consideration paid to the shareholder during the pendency of the 262 appraisal proceeding. $" 100$

The first reform provides a threshold limitation that seeks to eliminate "de minimis" appraisal claims designed solely to gain leverage

\footnotetext{
94. Id.

95. Korsmo \& Myers, supra note 3, at 1580.

96. Wolf et al., supra note 12 , at 2.

97. Id.

98. S.B. 75, 148th Gen. Assemb. (Del. 2015).

99. Frawley et al., supra note 14.

100. Id.
} 
in settlement negotiations in limited public company transactions. ${ }^{101}$ This limitation on so-called "nuisance claims" has been criticized for not doing enough to limit the types of claims that are considered appraisal arbitrage. ${ }^{102}$ However, the second reform dealing with the statutory interest rate would give corporations the option to pay off appraisal petitioners at an earlier stage of the appraisal process, as a means of ceasing the accrual of interest. ${ }^{103}$

If the statutory interest reform were put in place, it would give the surviving corporation of a merger the option to pay the appraisal petitioner a reasonable sum determined by the corporation at any time prior to a final judgment. ${ }^{104}$ Once the payment was made, interest would no longer accrue on the amount paid by the corporation. ${ }^{105}$ However, the corporation making such payments would be required to make the same payment to all appraisal claimants, unless there were a good faith basis for contesting a shareholder's entitlement to an appraisal. ${ }^{106}$ Such reforms are meant to address the growing concerns over increased appraisal activity by hedge funds attempting to take advantage of dissenting shareholders statutory appraisal rights. ${ }^{107}$

While the Delaware State Bar Association has approved the Bar's Appraisal Amendments, the Delaware legislature has not yet proposed any legislation adopting these reforms. ${ }^{108}$ Attorneys have concluded that the lack of proposed legislation may be due to an "industry concern that the proposed amendments do not go far enough" to limit appraisal arbitrage by, for example, "denying appraisal rights for shares purchased after the announcement of the merger or at least after the record date."109 However, there is still optimism (even if only my own) for the Bar's Appraisal Amendments to be improved and become adopted legislation in 2016 or subsequent years. While statutory interest significantly

\footnotetext{
101. Richards, Layton, \& Finger, 2015 Amendments to the General Corporation Law of the State of Delaware (Apr. 13, 2015), https://www.rlf.com/Publications/6017.

102. Patrick Diaz \& Anne Johnson Palmer, Proposed Amendments Address Appraisal Arbitrage, INTERNATIONAL LAW OFFICE 1 (June 24, 2015), https://www.google.com/url?sa=t\&rct=j\&q=\&esrc=s\&source=web\&cd=1\&ved=0CB0QFjAAahUK Ewi07JG06frIAhXD4yYKHQToB6M\&url=https\%3A\%2F\%2Fwww.ropesgray.com\%2F \%2Fmedi a\%2FFiles\%2Farticles\%2F2015\%2FJune \%2F20150624_ILO_Article.ashx\&usg=AFQjCNFcTZruN p_yDVUBpVYM8H-k-_nhQ\&sig2=8R54E2SyWahDRjT1U12Mcg.

103. Richards, Layton, \& Finger, supra note 101.

104. Id.

105. Id

106. Id.

107. Diaz \& Palmer, supra note 102, at 1 .

108. Frawley et al., supra note 14.

109. Id.
} 
increases the occurrence of appraisal arbitrage, the method of valuation in an appraisal proceeding provides another complex layer promoting appraisal arbitrage.

\section{F. Valuation in an Appraisal Proceeding}

A brief background of the valuation methods courts implement to determine the "fair value" of appraisal petitioner's shares is essential to understanding the overall impact of appraisal arbitrage. If an appraisal claimant satisfies the procedural requirements, valuation determines whether the claimant will receive a monetary award for their stock. While typically courts will rely on valuation experts using a discounted cash flow valuation method or something similar to determine "fair value," a recent trend may indicate that Delaware courts are beginning to heavily rely on the merger price.

\section{Valuation Methodology Used in Delaware}

When the Delaware courts are faced with assigning a value to the sale of a corporate enterprise they are confronted with an extremely complex analysis. ${ }^{110}$ When evaluating the sale price of a simple asset, the market value is considered to be the true fair value of the asset. ${ }^{111}$ However, section 262(h) does not adhere to this principle due to the complexity involved when assessing the value of the sale of a corporate enterprise. ${ }^{112}$ The Delaware Supreme Court has clarified that "in appraisal actions, this court must not begin its analysis with a presumption that a particular valuation method is appropriate, but must instead examine all relevant methodologies and factors, consistent with the appraisal statute."113 This precedent obligates the court to use "all relevant factors" when evaluating the fair value of a company's transaction. $^{114}$

Typically, the court relies on expert valuations from both the merging corporation and the dissenting shareholders, which commonly use a discounted cash flow analysis or other comparable company

110. Huff Fund Inv. P'ship v. CKx, Inc., No. 6844-VCG, 2013 WL 5878807, at*1 (Del. Ch. Nov. 1, 2013), aff'd, 2015 WL 631586 (Del. Feb. 12, 2015).

111. Id.

112. Id.

113. Merion Capital LP v. BMC Software, Inc., No. 8900-VCG, 2015 WL 6164771, at *1 (Del. Ch. Oct. 21, 2015) (citing Golden Telecom, Inc. v. Glob. GT LP, 11 A.3d 214, $217-18$ (Del. 2010)); Del. Code ANN. tit. 8, § 262(h) (West 2006 \& Supp. 2016).

114. Huff, 2013 WL 5878807, at*1. 
analyses to assess the statutory fair value. ${ }^{115}$ In addition, the market value (the sale price of the corporation) is sometimes used when the court determines it is reasonably derived. ${ }^{116}$ Expert valuations can provide the court with figures ranging from below the sale price to more than twice the actual sales price of the transaction. ${ }^{117}$ Overall, Delaware courts are provided with an abundant amount of information making the determination of fair value a difficult process.

\section{Usage of the Merger Price as "Fair Value"}

Historically, the court has relied on the merger price in limited circumstances as evidence of fair value if the events leading to the transaction are considered reliable indicators of the transaction's value and merger-specific value is excluded. ${ }^{118}$ In 2010, the court in Golden Telecom, Inc. v. Global GT $L P^{119}$ declined to adopt a rule requiring the Chancellor or Vice Chancellors to defer conclusively or presumptively to the deal price as the best indication of fair value in an appraisal proceeding. ${ }^{120}$ The court stated:

Section 262(h) unambiguously calls upon the Court of Chancery to perform an independent evaluation of "fair value" at the time of a transaction. It vests the Chancellor and Vice Chancellors with significant discretion to consider "all relevant factors" and determine the going concern value of the underlying company. Requiring the Court of Chancery to defer-conclusively or presumptively - to the merger price, even in the face of a pristine, unchallenged transactional process, would contravene the unambiguous language of the statute and the reasoned holdings of our precedent. It would inappropriately shift the responsibility to determine "fair value" from the court to the private parties. Also, while it is difficult for the Chancellor and Vice Chancellors to assess wildly divergent expert opinions regarding value, inflexible rules governing appraisal provide little additional benefit in determining "fair value" because of the already high costs of appraisal actions. Appraisal is, by design, a flexible process. Therefore, we reject Golden's contention that the Vice Chancellor erred by insufficiently deferring to the merger price, and we reject its call to

\footnotetext{
115. Id.

116. Id

117. Id

118. Kevin R. Shannon \& Christopher N. Kelly, Ckx Decisions Reveal Developments in Delaware Stock Appraisal Rules, 28 WESTLAW J. DEL. CoRP. 1, 2 (2014).

119. 11 A.3d 214 (Del. 2010).

120. Id. at 219 .
} 
establish a rule requiring the Court of Chancery to defer to the merger price in any appraisal proceeding.

While in certain situations the merger price is a reliable indicator of fair value, the Golden Telecom decision blurs its beneficial application in determining fair value.

This opinion along with multiple cases declining to give any value to the merger price ${ }^{122}$ led practitioners to believe that when the court begins evaluation of fair value, the merger price was irrelevant and unreliable. ${ }^{123}$ However, the recent decision of Huff Fund v. CKx $x^{124}$ provided a valuation that solely relied on the merger price because the sales process resulted in "an arms-length merger price resulting from an effective market check." 125 Such a ruling is important precedent for future appraisal petitions, and resolves an issue of debate among practitioners who doubt the courts' value of the merger price in appraisal cases. ${ }^{126}$ Following suit, Delaware courts have started to use the transaction's merger price as a correct assessment of "fair value" for appraisal proceedings more frequently. ${ }^{127}$ Such courts have relied on the merger price for various reasons ranging from a lack of reliable alternative evaluation methods ${ }^{128}$ to a determination that the merger price was derived from an untainted and arms-length sales process. ${ }^{129}$ However, recently the Delaware Court of Chancery in In re Appraisal of Dell, Inc. provided that even in the face of an arms-length sales process, the court is not required to rely on the merger price to determine fair value. ${ }^{130}$ While the courts must not give a presumption to a single evaluation method, many courts have come to view the merger price as an acceptable method of determining "fair value."" Overall, the court may

121. Id. at $217-18$ (emphasis in original).

122. See, e.g., Merion Capital, L.P. v. 3M Cogent, Inc., No. 6247-VCP, 2013 WL 3793896, at *5 (Del. Ch. July 8, 2013); In re Orchard Enters., Inc., No. 5713-CS, 2012 WL 2923305 (Del. Ch. July 18, 2012).

123. Huff Fund Inv. P'ship v. CKx, Inc., No. 6844-VCG, 2013 WL 5878807, at*11 (Del. Ch. Nov. 1, 2013), aff'd, 2015 WL 631586 (Del. Feb. 12, 2015).

124. Id.

125. Id.

126. Shannon \& Kelley, supra note 118 , at 2.

127. See e.g., Merion Capital LP v. BMC Software, Inc., No. 8900-VCG, 2015 WL 6164771, at *18 (Del. Ch. Oct. 21, 2015); In re Appraisal of Ancestry.com, Inc., No. 8173-VCG, 2015 WL 399726 (Del. Ch. Jan. 30, 2015); Huff, 2013 WL 5878807, at*1 (finding that "use of the merger price to determine fair value is appropriate in this matter").

128. Huff, 2013 WL 5878807, at*11.

129. Ancestry.com, Inc., 2015 WL 399726, at*16.

130. No. 9322-VCL, 2016 WL 3186538, at*22-25 (Del. Ch. May 31, 2016).

131. See, e.g., Merion Capital, 2015 WL 6164771, at *1; Ancestry.com, Inc., 2015 WL 399726, 
be faced with "wildly divergent expert opinions regarding value"132 and there seems to be a trend of using the merger price to determine the fair value of a transaction. ${ }^{133}$

\section{Merger Price Valuation Regarding "Interested" and "Disinterested" Transactions}

From 2010 to 2014, Delaware courts determined in seven of nine cases that the fair value of appraisal petitioners' shares was higher than the agreed on merger price. ${ }^{134}$ Only one of the cases had an appraisal award that was lower than the merger price, and there was only one case in which the appraisal award was the same as the agreed on merger price. ${ }^{135}$ The courts deemed five of the seven cases that resulted in a higher appraisal price over the agreed merger price as "interested transactions," 136 while two of the cases were labeled as "disinterested transactions." 137 Both cases that did not result in a higher appraisal price than the actual merger were considered disinterested transactions. ${ }^{138}$

The five appraisal claims regarded as interested transactions received appraisal awards significantly above the merger price ranging from $19.5 \%$ to $148.8 \%$ above the merger price. ${ }^{139}$ In contrast, the four transactions labeled as disinterested, had only two determinations of

\footnotetext{
at *16; Huff, $2013 \mathrm{WL} 5878807$, at *11 (finding that "use of the merger price to determine fair value is appropriate in this matter").

132. Golden Telecom, Inc. v. Glob. GT LP, 11 A.3d 214, 218 (Del. 2010).

133. See, e.g., Merion Capital, 2015 WL 6164771, at *1; Ancestry.com, Inc., 2015 WL 399726, at *16; Huff, 2013 WL 5878807, at*11.

134. See, e.g., Laidler v. Hesco Bastion Envtl., Inc., No. 7561-VCG, 2014 WL 1877536, at *2, *14 (Del. Ch. May 12, 2014); Merion Capital, L.P. v. 3M Cogent, Inc., No. 6247-VCP, 2013 WL 3793896, at*1 (Del. Ch. July 8, 2013); Towerview LLC v. Cox Radio, Inc., No. 4809-VCP, 2013 WL 3316186, at*1 (Del. Ch. June 28, 2013); IQ Holdings, Inc. v. Am. Commercial Lines Inc., No. 6369-VCL, 2013 WL 4056207, at*1-4 (Del. Ch. Mar. 18, 2013); Gearreald v. Just Care, Inc., No. 5233-VCP, 2012 WL 1569818, at *1 (Del. Ch. Apr. 30, 2012); Glob. GT LP v. Golden Telecom, Inc., 993 A.2d 497, 498-99 (Del. Ch. Apr. 23, 2010), aff'd, Golden Telecom, Inc. v. Glob. GT LP, 11 A.3d 214, 218 (Del. Dec. 29, 2010); In re Sunbelt Beverage Corp. S'holder Litig., No. 16089CC, 2010 WL 26539, at *1 (Del. Ch. Feb. 15, 2010); In re Orchard Enters., Inc., No. 5713-CS, 2012 WL 2923305, at*23 (Del. Ch. July 18, 2012); Huff, 2013 WL 5878807, at *1.

135. Huff, 2013 WL 5878807, at*1; Gearreald, 2012 WL 1569818, at*1.

136. The Delaware court system considers a transaction to be "interested" if it involves a transaction in which a director, stockholder, or other affiliate of a corporation has some form of control over both parties in the transaction. Robert R. Carlson, Scott B. Joachim, \& Stanley C. Liu, Interested Party Transactions: Lessons from Loral 1 (Jan. 2009), https://www.paulhastings.com/docs/default-source/PDFs/1144.pdf.

137. Mei, supra note 8, at 86 .

138. Huff, 2013 WL 5878807, at*1; Gearreald, 2012 WL 1569818, at*1.

139. Bomba et al., supra note 2, at 3 .
} 
value above the merger price, with the highest being a $15.6 \%$ increase. ${ }^{140}$ Such a blatant difference in appraisal determinations is likely an attempt to protect minority shareholders from interested transactions. ${ }^{141}$

Overall, the method of reaching the fair value of shares fluctuates based on the facts of the case. However, the information stemming from recent cases might suggest that an option to limit appraisal arbitrage in valuation proceedings may lie in the corporation's deal structure. While corporations have the ability to structure a deal that reduces the likelihood of a successful appraisal claim, the focus should be targeted on a dissenting shareholder's eligibility to bring an appraisal claim. The reforms explored in Part III of this Comment limit hedge funds and activist shareholders' eligibility to bring an appraisal claim in the first place and effectively limit the practice of appraisal arbitrage.

\section{ANALYSIS}

The most effective solution to limiting the practice of appraisal arbitrage conducted by hedge funds and activist shareholders lies in a two-prong legislative reform of section 262. The reform will aim to heighten the amount of risk arbitrageurs take when engaging in appraisal arbitrage. The reduction of appraisal arbitrage will positively impact merger transactions across the nation by minimizing deal threatening litigation and providing more confidence in pricing negotiations between potential merging partners. An amendment to Delaware statutes sets the precedent for states across the country (including Kansas) ${ }^{142}$ that model their state corporation law after Delaware, and significantly impacts the majority of corporations incorporated in Delaware. In addition, limiting appraisal arbitrage will also aid to reduce the larger picture of predatory shareholder litigation that, in effect, has become a standard "deal tax" on merger transactions. ${ }^{143}$ While arguments exist that appraisal arbitrage is

\footnotetext{
140. Id.

141. Mei, supra note 8 , at 87.

142. Edwin W. Hecker, Jr., Fiduciary Duties in Business Entities, 54 U. KAN. L. ReV. 975, 975 (2006) (stating that Kansas has "consciously chosen to follow Delaware's lead in business legislation" and citing examples of Kansas courts articulating this choice).

143. In the past five years, predatory shareholder litigation has occurred in $90 \%$ of merger transactions. While the majority of these suits end in an early settlement, the predictability and frequency of these suits has led predatory shareholder litigation to be characterized as a "deal tax" on merger activity. Tyler O'Connell, Emily Burton \& Julia B. Ripple, Reducing the "Deal Tax": Delaware's Recent Scrutiny of Non-Monetary Settlements 1 (Sept. 16, 2015), https://www.google.com/url? sa=t\&rct=j\&q=\&esrc=s\&source=web\&cd=6\&ved=0ahUKEwjKhuPLr e7KAhWGPCYKHfWTDp4QFgg-

MAU\&url=http\%3A\%2F\%2Fapps.americanbar.org\%2Fdch\%2Fthedl.cfm\%3Ffilename\%3D\%2FCL
} 
a useful side effect of section 262 that benefits public shareholders, ${ }^{144}$ eliminating appraisal arbitrage will benefit not only the Delaware court system and merger transactions across the country, but would also limit appraisal actions to the shareholders section 262 was initially designed to protect.

The first prong to limiting appraisal arbitrage lies in amending section 262 to state expressly that appraisal rights are not available to a shareholder that purchases shares of a merging corporation after the record date. Such an amendment would effectively overrule the decisions in In re Appraisal of Transkaryotic Therapies, Inc. and In re Appraisal of Ancestry.com, Inc. However, this reform is in line with the Delaware courts' decisions by placing reform in the hands of the legislature rather than the judiciary. ${ }^{145}$ The second prong to eliminating appraisal arbitrage lies in reducing the statutory interest rate that provides appraisal petitioners 5\% interest above the then current Federal Reserve interest rate.

The two-prong solution outlined above will significantly limit appraisal arbitrage by heightening the risk appraisal arbitrageurs must take when bringing an appraisal claim, while maintaining protection for the dissenting shareholders the statute was designed to protect. In addition, the Delaware courts' recent trend of utilizing the merger price as the "fair value" for shares when conducting valuation in an appraisal proceeding is a step in the right direction towards limiting appraisal arbitrage. Overall, the suggested reforms to section 262 provide a great advantage to the Delaware court system and to corporations involved in merger transactions by significantly limiting the number of hedge funds attempting to take advantage of a statute designed to protect dissenting shareholders.

\section{A. Eliminating Appraisal Arbitrage Starts with Abolishing the Economic Incentives}

The recent upswing in hedge fund and activist shareholder use of appraisal arbitrage has created a substantial negative impact on the

\footnotetext{
$150000 \% 2$ Fsitesofinterest_files\%2Fdeal_tax.PDF\&usg=AFQjCNHELaZ6DiyS_0cmI4bZyL5poZ̄eqA\&sig2=mZOg_LYAZ4QDwi0B111GcQ.

144. Korsmo \& Myers, supra note 3, at 1553 (arguing appraisal arbitrage may benefit public shareholders).

145. In re Appraisal of Transkaryotic Therapies, Inc., No. 1554-CC, 2007 WL 1378345, at *5 (Del. Ch. May 2, 2007) (stating that the decision is a result of statutory interpretation, and the solution to eliminate appraisal arbitrage lies in amending section 262).
} 
mergers and acquisitions market. Merging companies face substantial risks as they consider a potential merger including: a large appraisal judgment, coercion from a strong group of dissenting shareholders, and a threat to the success and profitability of the overall merger.

\section{Appraisal Arbitrage Imposes Consequences on the Success of Merger Transactions}

One of the largest threats appraisal arbitrage presents is to the deal dynamics between merging companies. ${ }^{146}$ "[P]otential buyers of companies must now assess the possibility of appraisal actions being brought against them" forcing companies in merger transactions to evaluate additional risks in the transaction. ${ }^{147}$ The structure of the deal and the process towards reaching a conclusive sales price between the parties can be a significant factor in the likelihood of a substantial appraisal award. ${ }^{148}$

The potential of being faced with a large appraisal proceeding forces many companies to reach a settlement with shareholders before the court grants a large judgment. ${ }^{149}$ Activists will publicly and aggressively encourage other stockholders to join in an appraisal action, "increasing the threat of the proceeding to the target board - and thus, as a result, the activist's leverage in negotiating a settlement," presenting a serious threat to the ultimate success of a deal. ${ }^{150}$ The easy answer would be for corporations to structure their deals with the anticipation of potential appraisal litigation as a cost factor. However, the effects and probability of a significant appraisal award or substantial interest payment can be extremely difficult for a company to predict. ${ }^{151}$ The mechanics of structuring a transaction in anticipation of such litigation, in addition to the regular fiduciary litigation that commonly accompanies merger transactions, presents a substantial problem. ${ }^{152}$

In addition, the target company's sale process is "unknown to the buy-side party until the company's proxy statement is furnished to the shareholders." 153 Buyers have no certainty as to whether the seller may

\footnotetext{
146. Bomba et al., supra note 2 , at 2 .

147. Mei, supra note 8, at 88-89.

148. Bomba et al., supra note 2, at 4 .

149. Id. at 3 .

150. Id. at 2-3.

151. Id. at 4-5.

152. Id. at 4 .

153. Id. at 5 .
} 
have incorrectly prepared the selling corporation's projections or a myriad of other possibilities subjecting the deal to an increased risk of appraisal petitions. ${ }^{154}$ Overall, appraisal litigation has a significant effect on the development and success of potential merger transactions, and such litigation is extremely difficult to structure into a potential deal.

\section{Appraisal Arbitrage Postures Merging Parties in an Adversarial Position}

There is also a major concern that both buyers and sellers will struggle to find an appropriate price for the merger transaction. ${ }^{155}$ Buyers may account for the potential cost of appraisal litigation through the use of appraisal conditions. ${ }^{156}$ Appraisal conditions often provide "a condition to the merger that not more than a specified percentage, often $10 \%$, of the outstanding target shares seek appraisal rights. ${ }^{, 157}$ If there are dissenting shareholders that exceed the specified threshold limit, an acquirer may decide to not close the transaction. ${ }^{158}$

Conditions such as these have the potential to put buyers and sellers at odds. ${ }^{159}$ Sellers are likely to resist any appraisal closing condition as a part of the merger, and if they compromise and concede to one, they will likely advocate for the condition to be set very high. ${ }^{160}$ Buyers that have not negotiated an appraisal rights condition, may be confronted with an exceedingly large payment to dissenting shareholders as a result of an appraisal action, increasing the likelihood that the negotiated financing provided to structure the deal will be inadequate. ${ }^{161}$ The outcome of this negotiation will vary significantly, but it will undoubtedly be a difficult topic for both parties and can potentially cause the deal not to close. ${ }^{162}$

An appraisal condition can be of consequence to both the seller and the buyer, by providing shareholders with leverage and inviting coercive shareholder behavior that both sides of the transaction would like to

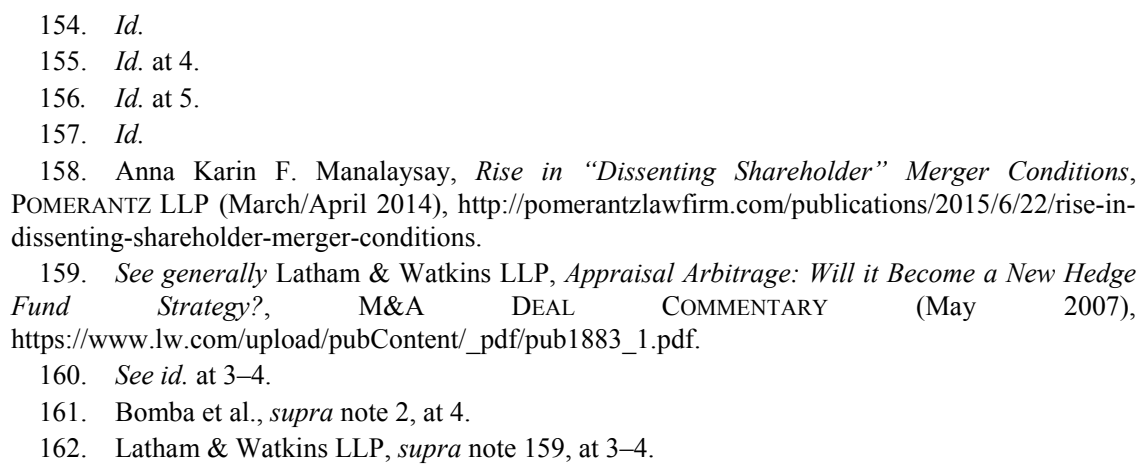


discourage. ${ }^{163}$ For instance, if a transaction is headed in the direction of a positive shareholder vote, an appraisal condition may create leverage for the dissenting shareholders to threaten the success of the entire transaction. ${ }^{164}$ Overall, "an appraisal condition sets up a very unfavorable negotiating dynamic for the buyer and is not in the longterm interests of the seller" ${ }^{\text {"165 }}$ effectively creating a notable threat to the success of the merger.

In addition, the possibility of a large dissenting shareholder payout may not arise until a time significantly past closing. ${ }^{166}$ This leaves buyers with a large judgment while attempting to lead a recently merged corporation. These risks come with additional concerns including fear that a shareholder vote requiring a majority of the shares outstanding in favor of the merger may not be attainable. ${ }^{167}$ Lastly, there remains a large degree of uncertainty as to the methods a court will use to determine the fair value of the shares in an appraisal action. ${ }^{168}$ Overall, reforms are needed to eliminate the practice of appraisal arbitrage as it continues to grow because the practice is having a significant negative impact on the merger and acquisition market.

\section{B. Overruling Transkaryotic and Ancestory.com Makes Sense Because} it Eliminates Economic Advantage and Aligns with the Legislative Purpose Behind Section 262

The signature piece of proposed legislation discussed in this Comment preempts the Transkaryotic decision by amending section 262 to prohibit appraisal rights for shareholders that purchase shares of a merging corporation after the record date. Such a reform is being highly sought after by corporations and firms across the country. A group of large Wall Street law firms ${ }^{169}$ have banded together to urge the Delaware legislature to limit appraisal arbitrage by prohibiting the eligibility of

\footnotetext{
163. Id. at 3 .

164. Id.

165. Id.

166. Andrew J. Noreuil, Dissenting-Shareholders Clauses May Become More Common, LAW 360 (Feb. 2014), http://www.law360.com/articles/510471/dissenting-shareholders-clauses-maybecome-more-common.

167. Bomba et al., supra note 2, at 4-5.

168. Id. at 5 .

169. Liz Hoffman, Wall Street Law Firms Challenge Hedge-Fund Deal Tactic, WaLl STREET J. (April 6, 2015, 8:53 PM), http://www.wsj.com/articles/wall-street-law-firms-challenge-hedge-funddeal-tactic-1428362171 (listing of the law firms involved: Cravath, Swaine \& Moore LLP; Davis Polk \& Wardwell LLP; Latham \& Watkins LLP; Skadden, Arps, Slate, Meagher \& Flom LLP; Simpson Thacher \& Bartlett LLP; Sullivan \& Cromwell LLP; and Wachtell, Lipton, Rosen \& Katz).
} 
appraisal rights for shares purchased after the record date. ${ }^{170}$ These law firms' top clients are the private equity buyers and target companies that face the risks outlined above, and suffer the consequences of appraisal arbitrage. ${ }^{171}$ The firms reasoned that prohibiting the purchase of a merging company's shares after the record date would "reduce the unseemly claims-buying that is rampant and serves no legitimate equitable or other purpose."172

\section{The Economic Advantage Stemming From Transkaryotic}

The proposed reforms will significantly limit the investment practice of appraisal arbitrage by eliminating a hedge fund or activist shareholder's economic advantage of purchasing shares after the record date. In a typical merger transaction, the merger is announced to the public and then the record date for the shareholder meeting is set. ${ }^{173}$ As provided by Transkaryotic, a hedge fund or activist shareholder has the opportunity to buy shares of a merging company after the record date and up until the eve of the shareholder vote on the transaction and still remain eligible for appraisal rights. ${ }^{174}$ Ultimately, Transkaryotic allows appraisal rights for shares that may have even been voted in favor of the merger by a previous shareholder if purchased after the record date. ${ }^{175}$ Preventing hedge funds and activist shareholders from surveying the corporate landscape up until the shareholder vote or the merger's closing will significantly assist in limiting the amount of disingenuous appraisal litigation taking place because it revokes the valuable economic advantage of bringing a claim.

2. The Ability to Purchase Shares After The Record Date Alters the Intended Purpose of Section 262

"It is well established in finance that the ability to delay an investment is valuable because it allows the investor to make a more

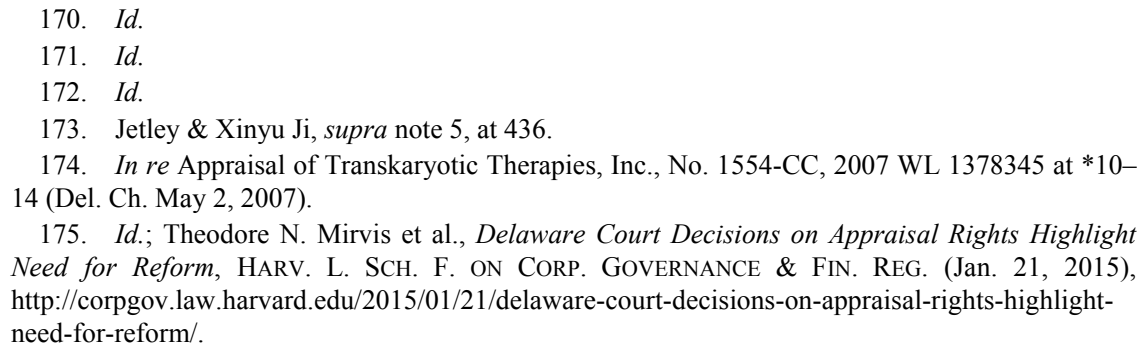

175. Id.; Theodore N. Mirvis et al., Delaware Court Decisions on Appraisal Rights Highlight Need for Reform, HarV. L. SCH. F. ON CORP. GOVERnANCE \& Fin. Reg. (Jan. 21, 2015), http://corpgov.law.harvard.edu/2015/01/21/delaware-court-decisions-on-appraisal-rights-highlightneed-for-reform/. 
informed investment decision."176 Appraisal arbitrageurs are being given this valuable advantage by having the ability to purchase shares after the record date. Under section 262(d)(1), a shareholder seeking appraisal must submit a written demand prior to the shareholder vote. ${ }^{177}$ On average, there is a total of 32 days between the notice date and the shareholder vote. ${ }^{178}$ However, in practice the interpretation of the statute has led to generic written demands without a specific number of shares listed for appraisal. ${ }^{179}$ This allows for flexibility to increase the amount of shares for appraisal up to the closing of the merger. ${ }^{180}$ When looking at a typical merger transaction "the average time period between the record date and deal consummation is 74 days." 181 Having the ability to survey the market landscape after the record date for an average of 74 days before closing provides such investment strategists with surety in the profitability of the mergers in which they seek appraisal. Whether an appraisal arbitrageur has an additional 32 or 74 days, this extra time not only allows dissenting shareholders to survey the market landscape, but also provides additional time to analyze proxy statements and newly disclosed information that would make an appraisal claim more or less attractive. ${ }^{182}$

Closing this time period gap heightens the risk of an appraisal claim for all hedge funds and activist shareholders attempting to take advantage of section 262. The original purpose of section 262 was to protect the long-term investors in a company who are wronged by being forced out at an unfair price. The proposed legislation stands to fulfill the legislative purpose of protecting dissenting shareholders, while reducing the amount of appraisal arbitrage and its negative effect on corporations across the nation.

\section{The Misguided Policy Rationale of the Recent Section 262 Proposed Amendments}

The Bar's Appraisal Amendments to section 262 that have yet to be enacted by the Delaware legislature fail to heed the cry of the merger and acquisition community by providing a provision limiting appraisal claims

\footnotetext{
176. Jetley \& Xinyu Ji, supra note 5, at 433.

177. Del. Code ANN. tit. 8, § 262(d)(1) (West 2006 \& Supp. 2016).

178. Jetley \& Xinyu Ji, supra note 5 , at 436 .

179. Id. at 435 .

180. Id

181. Id. at 436

182. Id. at $436-37$.
} 
to shareholders who purchased their shares before the record date. The Delaware State Bar Association appointed a subcommittee of the Corporate Law Section (the "Council") to evaluate the scope of the amendments to section 262 and whether the statute should limit appraisal arbitrage. ${ }^{183}$ Ultimately, the Council chose not to include the Bar's Appraisal Amendments, and published an accompanying paper that provides the Council's reasoning for concluding not to include amendments limiting appraisal arbitrage in Delaware Senate Bill $75 .{ }^{184}$ While the economic advantage of purchasing shares after the record date has been conclusively shown to benefit hedge funds and activist shareholders, ${ }^{185}$ the Council's reasoning for failing to limit appraisal arbitrage has yet to be analyzed.

1. Eliminating Appraisal Arbitrage Furthers the Council's Policy

Objective of Protecting Dissenting Shareholders by Eliminating

Parties the Statute Never Intended to Protect and Preserving

Appraisal for Deserving Shareholders

The Council provided various reasons as to why it decided not to limit the practice of appraisal arbitrage. Overall, it stated that the "Council does not believe appraisal arbitrage upsets a proper balance between the ability of corporations to engage in desirable value enhancing transactions and the ability of dissenting stockholders to receive fair value for their holdings." 186 While the Council's arguments seemingly provide valid legislative policy, the Council fails to provide adequate reasoning for its decision not to limit appraisal arbitrage. There is an incentive to encourage corporations to engage in desirable value enhancing transactions, and the goal is to preserve the ability of dissenting stockholders to receive fair value in their shares when faced with a merger. However, the Council's statement and the supporting materials do not provide sufficient reasoning for its failure to limit the purchase of shares after the record date, even when faced with overwhelming economic and policy arguments supporting such a limitation.

The proposal to limit the purchase of a corporation's shares after the

\footnotetext{
183. Lowenstein Sandler LLP, Section 262 Appraisal Amendments (Mar. 6, 2015), https://www.lowenstein.com/files/upload/DGCL\%20262\%20Proposal\%203-6- 
record date fully supports and aligns with the Council's policy rationale rather than opposing it. Eliminating or substantially limiting the practice of appraisal arbitrage by preventing the purchase of a corporation's shares after the record date aligns with the balance the Council values because it incentivizes corporations to reach a fair transaction price and restores the legislative purpose of section 262. A corporation is likely to be further incentivized to reach a fair transaction price because a reduction in the likelihood of a large appraisal proceeding minimizes the concern of a large unanticipated post-closing cost. ${ }^{187}$ With less risk in the closing of a transaction, companies can focus on reaching the best deal price possible for its shareholders. Corporations will likely still face an appraisal action by dissenting shareholders if a transaction produces an unfair or unsuitable price. However, without appraisal arbitrage claims, corporations will not be faced with insurmountable appraisal actions brought by appraisal arbitrageurs looking to capitalize on a loophole in section 262. The Council's rationale for not enacting a limitation to appraisal arbitrage is flawed because the elimination of appraisal arbitrage will enhance its objective rather than work in the opposite direction.

2. The Council's Failure to See the Economic and Policy Incentives to Limit Appraisal Arbitrage

Eliminating appraisal arbitrage furthers the Council's policy objective of protecting dissenting shareholders by eliminating claim buying hedge funds the statute never intended to protect, while preserving the right to appraisal for dissenting shareholders that have been long time holders of a merging corporation's stock. Eliminating appraisal arbitrageurs furthers the Council's position because it reinforces the legislative purpose section 262 was designed to uphold. ${ }^{188}$ The Council's policy rationale essentially states that there is no reason to eliminate appraisal arbitrage because dissenting shareholders are still protected. This point dismisses the fact that appraisal arbitrage is causing substantial harm to the merger and acquisition community and simply ignores the root cause of the problem. Eliminating appraisal arbitrage rectifies its negative impact on corporations while maintaining appraisal rights for the shareholders section 262 was designed to protect. Overall, the Council produced a policy rationale that overlooks the real

187. See Bomba et al., supra note 2, at 2 (providing that appraisal proceedings present a large unknown closing cost to companies determining the merger price of a transaction).

188. Thompson, supra note 18, at 13 (describing the purpose of section 262). 
economic and policy reasons to limit appraisal arbitrage, and fails to see that elimination of appraisal arbitrage furthers the Council's stated legislative policy.

\section{Amending Section 262 to Lower the Statutory Interest Rate Decreases the Leverage of Appraisal Arbitrageurs}

A second reform to substantially limit appraisal arbitrage includes lowering the statutory interest rate from $5 \%$ to $2.5 \%$ in excess of the Federal Reserve discount rate. This reform will reduce the economic advantage of bringing an appraisal claim while continuing to protect the dissenting shareholders section 262 was designed to shelter. As previously noted, the Delaware State Bar Association has approved minor reforms to allow for a company's option to pay and limit the accrual of interest. ${ }^{189}$ While these proposed amendments provide some relief to corporations facing appraisal litigation, they fail to go far enough in actually limiting the actual appraisal actions with which corporations deal. The amendments must lower the initial incentive for appraisal petitioners to bring a claim by lowering the statutory interest rate such petitioners will receive while their appraisal claim is pending.

1. The Bar's Appraisal Amendments Neglect a Viable Solution

Section 262(h) provides an award of interest to appraisal petitioners equal to Delaware's legal rate of interest (The Federal Reserve discount rate) plus $5 \% .{ }^{190}$ This award is distributed to appraisal petitioners regardless of the overall outcome of the case and provides significant incentive to bring a claim. ${ }^{191}$ While the Bar's Appraisal Amendments would provide some relief to corporations dealing with appraisal litigation, the Bar should have taken the further step of reducing the statutory interest rate amount in section 262(h).

Reducing the statutory interest amount in section 262(h) provides a much simpler and effective solution because it eliminates the headache corporations must endure under the Delaware State Bar Association's proposed amendments. Under the Bar's Appraisal Amendments, corporations may pay a cash amount to the dissenting shareholder before the appraisal proceeding ends, effectively limiting the accrual of

189. Richards, Layton \& Finger, supra note 101.

190. Del. Code ANN. tit. 8, § 262(h) (West 2006 \& Supp. 2016).

191. Swann \& Gewirtz, supra note 53, at 1 . 
statutory interest during litigation. ${ }^{192}$ Scholars have concluded that this amendment may decrease the amount of unmeritorious appraisal claims and effectively reduce the amount of interest a corporation must pay appraisal petitioners. ${ }^{193}$ However, the amendment creates problems for corporations, which would not exist if the Bar simply reduced the overall interest rate in section 262(h).

\section{A Simple Solution May Restore the Intended Purpose of Statutory Interest}

The biggest issue statutory interest poses to merging corporations is the amount of interest that should be paid out during the appraisal proceeding. The Bar's Appraisal Amendments fail to include a "clawback mechanism" for a company to recoup any overpaid interest it provides to an appraisal litigant. ${ }^{194}$ Therefore, corporations must be careful not to overpay litigants because any excess payment would be presumably forfeited. ${ }^{195}$ In addition, corporations must take into consideration the strategic economic advantage of providing an upfront interest payment. ${ }^{196}$ It has been suggested that corporations may use the merger price as a guide to the upfront payment, but this is somewhat unreliable. ${ }^{197}$ While the merger price may be a reasonable guide, courts are sporadic in relying on the merger price to determine the appraised "fair value" of a transaction. ${ }^{198}$ Instead, Delaware courts typically rely on discounted cash flow and other appraisal methods to determine the fair value of the merger, which can produce an appraisal price that significantly differs, but is usually higher, than the merger price. ${ }^{199}$ While the Bar's Appraisal Amendments may provide a way for corporations to limit an appraisal petitioner's statutory interest, the amendment leads to an unclear and unreliable evaluation for corporations.

\footnotetext{
192. Richards, Layton \& Finger, supra note 101.

194. Id.

195. Id

196. Id.

197. Id.

198. Id.

199. Shannon, supra note 118, at 1-2.
}

193. Abigail Pickering Bomba et al., Fried Frank Discusses Proposed Appraisal Statute Amendments, Which Would Permit Companies to Reduce Their Interest Cost, ColuM. L. SCH. BluE SKY BLOG (Mar. 30, 2015), http://clsbluesky.law.columbia.edu/2015/03/30/fried-frank-discussesproposed-appraisal-statute-amendments-which-would-permit-companies-to-reduce-their-interestcost/. 
In addition, the prepaying of interest before the close of appraisal litigation might lead to the encouragement of appraisal arbitrage. ${ }^{200}$ A corporation that provides a large upfront payment to appraisal petitioners before the close of litigation may encourage appraisal claims because paying appraisal claimants a large value upfront effectively supplies capital to claimants to fund their appraisal claims. ${ }^{201}$ If a corporation provides appraisal petitioners the opportunity to fund their claims, it effectively reduces the cost and risk of bringing an appraisal action and has the opposite effect the Bar's Appraisal Amendments intend. ${ }^{202}$ While the proposed amendments may seem to provide a way for corporations to take away the economic advantage appraisal petitioners find in the section 262(h) statutory interest rate, the amendment may work against merging corporations by funding the petitioners' appraisal claim. If the Bar's Appraisal Amendments are altered to lower the statutory interest rate it stands to provide a simple solution to limiting the amount of appraisal arbitrage taking place.

\section{E. Using the Merger Price as a Factor to Determine "Fair Value" in Appraisal Decisions Gives Substance to a Fair Valuation}

As recent trends indicate, Delaware courts have recently settled on the merger price as a significant indicator of fair value in appraisal actions. The court should be commended for their efforts to reaffirm the consideration of the merger price in their analysis of "all relevant factors" leading to the finding of a statutory fair value. ${ }^{203}$ Overall, this recent trend towards the use of the merger price is a step in the right direction when evaluating the fair value of a transaction subject to an appraisal proceeding.

1. The Merger Price May be the Best Indication of Fair Value in Valuation Proceedings

The Delaware court's recent reliance on the merger price when determining "fair value" is a laudable effort because in a number of situations the merger price is the best indicator of fair value, and the

\footnotetext{
200. See Jetley \& Xinyu Ji, supra note 5, at $452-55$.

201. Id. at 455 .

202. Id

203. See Huff Fund Inv. P'ship v. CKx, Inc., No. 6844-VCG, 2013 WL 5878807, at*1 (Del. Ch. Nov. 1, 2013), aff'd, 2015 WL 631586 (Del. Feb. 12, 2015) (giving weight to the merger price in certain transactions deemed at arms-length).
} 
courts' increased usage of this factor suggests that appraisal arbitrage should only be available when flawed deals undervalue companies. ${ }^{204}$ The merger price is the best indicator of fair value when: (1) expert evaluations supplied by both sides of the appraisal action are considered particularly unreliable indications of value, and (2) when the sale process shows itself to be particularly reliable because the transaction was conducted at arms-length and with an effective market check. ${ }^{205}$ While some practitioners concluded that the decision in Golden Telecom discouraged the merger price as an indication of fair value, Delaware courts have put that assumption to rest in recent decisions indicating the merger price will be used when the facts of the transaction are appropriate. $^{206}$

\section{Using The Merger Price in the "Fair Value" Evaluation is a Step in} the Right Direction

Court decisions utilizing the merger price as a relevant factor should be commended because they stand to further incentivize corporations to meet the arms-length and market check standards the court uses to initiate the merger price as fair value in an appraisal proceeding. Corporations now have additional incentive to avoid appraisal actions of dissenting shareholders by structuring their sales process to represent an arms-length merger with adequate market checks because the courts have stood firm in using this valuation method when appropriate. ${ }^{207}$ The recent trend reinforces the Delaware courts' commitment to recognizing the merger price as fair value when-based on the facts of the transaction - a deal is conducted in a reasonable manner. While the amendments proposed in this Comment attempt to spearhead the qualifications a shareholder must meet before it has the right to bring an appraisal claim, this recent trend of court decisions potentially limit appraisal arbitrage through a corporation's use of self-help in statutory

204. Timothy W. Gregg \& Rebecca L. Butcher, The Latest Significant Delaware Appraisal Decisions and Potential Effects on Appraisal Litigation, Bus. L. TODAY 4 (October 2015), http://www.americanbar.org/content/dam/aba/publications/blt/2015/10/appraisal-litigation201510.authcheckdam.pdf.

205. Phillip Richter, Over-Reaction to Use of Merger Price to Determine Fair Value, HARV. L. SCH. F. ON CORP. GOVERNANCE \& FIN. REg. (May 1, 2015), http://corpgov.law.harvard.edu/2015/05/01/over-reaction-to-use-of-merger-price-to-determine-fairvalue/.

206. See, e.g., Huff, 2013 WL 5878807, at *11; In re Appraisal of Ancestry.com, Inc., No. 8173-VCG, 2015 WL 399726, at *15 (Del. Ch. Jan. 30, 2015).

207. See Huff, 2013 WL 5878807, at *11 (court used the merger price as fair value because the sales process was at "arms-length" and provided adequate market checks). 
appraisal proceedings regarding value. This case law trend is a great incentive towards limiting appraisal arbitrage. However, eliminating the purchase of shares after the record date and reducing the amount of statutory interest granted to appraisal petitioners provide the most efficient solutions.

\section{CONCLUSION}

The practice of appraisal arbitrage is a growing issue that negatively affects the corporate landscape of mergers across the country. The holdings of Transkaryotic and Ancestory.com have made it permissible for hedge funds and activist shareholders to purchase shares of a merging company after the record date. This standard has created a conclusive economic advantage to parties that seek to purchase claims through appraisal arbitrage resulting in countless negative effects on companies engaging in a merger. The courts have put the burden of fixing this valuable advantage on the Delaware legislature, which has yet to enact a reform to section 262 effectively ending appraisal arbitrage.

The clear and most effective solution to eliminate or at least limit appraisal arbitrage is a two-pronged statutory reform that (1) eliminates the purchase of a merging corporation's shares after the record date and (2) limits the statutory interest appraisal petitioners receive while an appraisal claim is decided. These amendments will increase the risk of bringing an appraisal action by decreasing the amount of time appraisal arbitrageurs have to examine the financial landscape of a transaction. In addition, this amendment will further the Delaware legislature's policy by limiting section 262 to protect the dissenting shareholders it was initially designed to protect, while furthering a corporation's incentive to reach a fair sales price. The Delaware legislature can let appraisal arbitrage continue to affect corporations across the United States or it can effectively resolve the issue by enacting amendments to substantially limit appraisal arbitrage. By eliminating the purchase of a merging corporation's shares after the record date, and limiting the statutory interest appraisal petitioners receive, Delaware can revitalize section 262 and ultimately close the floodgates on the practice of appraisal arbitrage. 